\title{
ГЕОРГ ЗИМЕЛ „СИРОМАШНИ, УВОД У СОЦИОЛОГИЈУ СИРОМАШТВА“"2
}

Књига Историја сиромаштва Г. Зимела може се сматрати полазиштем социологије сиромаштва у академском проучавању поменутог феномена. Основни допринос књиге огледа се у начинима на који се расветљава проблематика дефинисања сиромаштва, али и у пружању „алата“ за повезивање концепта сиромаштва са друштвом у целини. Премда неуобичајено за наведени период социолошког развоја и стваралаштва, ово Зимелово дело специфично приступа анализи и начину истраживања сиромаштва антиципирајући теоријски приступ који се профилисао знатно касније - конструкционизам.

Сходно самом наслову књиге и тематици, ауторове мотиве и осетљивост за питања маргинализације, друштвене искључености, сиромаштва, „странаца“" и сродних феномена можемо разумети сагледавајући контекст у којем је Зимел проучавао друштвене феномене (антисемитизам) и начине њиховог испољавања. Време у којем је аутор стварао одликује се потпуном маргинализацијом и искључивањем јеврејске популације из јавног, економског и културног живота. Комплексно друштвено окружење Зимелу пружа специфичан „хабитус“" који прожима његово стваралаштво и разумевање друштвених феномена сходно његовом статусу (Јевреја) у то доба. Премда је утицао на многе ауторе попут Роберта Парка, Херберта Ганса, Роберта Мертона, Норберта Елијаса и инспирисао многа истраживања о процесима социјалне дисквалификације и сиромаштва у САД, ово дело пружа увид и у неколико непознатих страна Зимеловог дела који приказују ауторову (само)рефелексију његовог богатог стваралаштва и научног доприноса. Књига поред Зимеловог поглавља Сиромашни садржи и изванредан Увод Сержа Погама и Франца Шултхајса, и слике и фотографије сиромаштва 19. и 20. века допуњене садржајним коментарима и објашњењима Дејана Аничића.

Оригинални допринос дела огледа се у иновативном приступу проблему и начину проучавања феномена сиромаштва. Насупрот добро етаблираном економистичком приступу сиромаштва (супстанцијалистичка дефиниција сиромашних), Зимел предлаже нови, сагледавајући сиромаштво у контексту друштва које „производи“ овај феномен ${ }^{3}$. Приступ проучавања сиромашних типичан за економисте усмерен је на дефинисање линије сиромаштва у једном

\footnotetext{
${ }^{1}$ aleksandra.nikolajevic@filfak.ni.ac.rs

${ }^{2}$ Књигу је објавила издавачку кућа Карпос из Лознице 2020. године.

${ }^{3}$ Нераздвојиво од друштва у којем се сиромаштво јавља.
} 
друштву (дефинисање минималног прихода потребног за преживљавање) што уско корелира са развојем мера социјалне политике у циљу смањења сиромашних. Зимел овакав приступ и узак фокус на дефинисање минималног прихода за преживљавање сиромашних тумачи као редукционистички и недовољан за социолошку ваљану анализу наведеног феномена, сходно чему пружа један нови приступ сиромаштву и другачију теоријску оријентацију. Аутор сиромашне не проучава ван контекста целине, већ их посматра као интегративне делове друштва у зависности од циљева истог. Блиско конструктивистичком приступу, у књизи детаљно елаборира своју идеју да сиромаштво не постоји само по себи (квантитативни показатељи сиромаштва) већ се јавља као реакција на неко постојеће стање којем друштво придаје одређено значење.

Поред пружања аналитичког оквира за проблематизацију питања сиромаштва у модерном друштву, у књизи се могу наћи и елементи за посматрање односа помоћи сиромашнима и шире заједнице, али и њихове функције за друштво у целини у једном историјском контексту (примери системског развоја државне помоћи у Немачкој, Великој Британији, Француској). Књига пружа историјски приказ јављања системске помоћи сиромашнима и осврт на прву институционализацију социјалних права из радног односа (државни принципи заштите). Аутор, међутим, наглашава да се разлике у друштвеним уређењима различитих земаља и организацији бриге о сиромашнима могу довести у везу са политичком културом друштва. Немачка је, рецимо, прва земља која је развила институционалну бригу о сиромашнима. Категорију „зависни од помоћи“ измешта у поље „под ризиком“, што је омогућено системом социјалног осигурања. Пошто је критеријум за остваривање ове врсте заштите био везан за радни статус, на прелазу из 19. у 20. век и даље је значајан обухват популације био искључен из програма социјалног осигурања (незапослени) сходно чему велики број грађана прима социјалну помоћ. Док формална и загарантована заштита остварена из радног односа путем система социјалног осигурања пружа извесну сигурност, популација која није обухваћена овим државним програмом (углавном жене, деца, породице са много деце, самохрани родитељи) била је стигматизована и до те мере изопштена из јавног живота да је губила право на гласање, политичку партиципацију и била присилно затварана. Зависни од помоћи били су, дакле, грађани другог реда. На овом примеру Немачке, али и других земаља, Зимел повезује врсте система бриге о сиромашнима са степеном развијености и типовима политичке културе у анализираним друштвима.

Поред конкретних историјских приказа развоја система социјалне сигурности и помоћи, аутор се бави и питањем помоћи сиромашнима у контексту друштвене функције које помоћ има за друштво у целини. Зимел подробно објашњава принцип помоћи и истиче три суштинска елемента која је одликују: 1. лична је и селективна (покрива само одређене појединце и само одређене потребе), 2. пружа се у интересу заједнице, не самих појединаца (функција помоћи је да оснажи појединце и спречи девијантна понашања која могу угрозити заједницу), 3. пружање помоћи доприноси одржању statusa quo (помоћ као фактор кохезије и равнотеже друштва). У том смислу, Зимлов макросоциолош- 
ки приступ у први план ставља утилитаристичку димензију друштвене подршке сиромашнима (самоодржање), а не филантропску и хуманитарну ноту. Право на помоћ, која касније произлази из концепта људских права, подлеже другачијем дефинисању у зависности од политичких и економских циљева у једној земљи. Политичко-економски циљеви могу да изнедре издашне програме потпоре сиромашнима или да их максимално редукују (посебно указујући на супсидијарност као механизам повлачења државе из подршке сиромашнима).

Насупрот системској (јавној) помоћи, аутор разматра и питање приватне анализирајући притом позитивне и негативне екстерналије. Његов приступ јавној и приватној помоћи не огледа се у њиховом супротстављању, већ напротив - у комплементарности њихових друштвених функција. Док се приватно доброчинство бави узроцима индивидуалне природе, заједница кроз јавну помоћ може да утиче на привредне и културолошке околности оснаживањем појединаца и стварањем предуслова за спречавање репродукције сиромаштва. Приватна помоћ би, у складу са наведеним, требало бити допуна јавној. Ширина се у ауторовом приступу не огледа у томе што Зимел дефинише основне елементе односа помоћи сиромашнима и друштву, већ у томе што приде анализира и њену еволуцију: са заједнице на државу; са локалног на друштвени ниво; са приватне на јавну помоћ; прелазак са непосредне видљивости сиромашних у апстрактне појмове сиромаштва; начине интервенције у пружању подршке сиромашнима и слично. Осврт на варијације друштвеног односа према сиромаштву, али и међусобну зависност друштвених елемената у целини и категорије сиромашних, још један су допринос ове књиге што аутор омогућава својом социо-историјском и компаративном перспективом.

Зимел пише да је човек друштвено биће нужно увучено у мрежу узајмних права и дужности (у којем је право примарни елемент) сходно чему дефинише концепт друштва. Аутор темељно образлаже супротстављеност социолошких и етичких категорија у контексту мреже права и дужности. На трагу реченог указује да постојање различитих концепција помоћи сиромашнима представља пример тог дуализма, и јавља се у осећају који руководи људским моралним поступањем. Друштво, стога, аутор дефинише као „узајамност бића која поседују права на основу моралних, правних, обичајних и многих других категорија, и само је (...) техничка последица права да то за друге значи дужност“ (37).

Различита социолошка полазишта другачије приступају „дужностима“ према сиромашнима. Теорије које проблем сиромаштва виде као производ друштвеног миљеа проналазе оправданим постојање дужности према сиромашнима у смислу компензације за животне шансе и прилике. Пошто то право нужно има своје границе - потешкоћа је одредити га у сваком појединачном смислу (критеријум за остваривање права на помоћ). Аутор подробно образлаже и остале проблеме приликом дефинисања подршке сиромашнима: 1. количина материјалне помоћи (квантитативна граница) која се изражава у новцу, и коју је знатно теже објективно одредити него помоћ у натури; 2. проблем усмерености права (од кога се очекује да пружи помоћ), односно, да ли се по- 
моћ очекује од појединца, породице, локалне заједнице, колектива, пријатеља, удружења итд.; 3. оправданост постојања захтева за подршку.

Уколико је брига о сиромашнима телеолошки оријентисана (зависи од циљева који њоме треба да се постигну), а не каузално (постојеће и делотворно јединство чланова групе), онда захтев сиромаха који би требало да проистиче из права губи на значају и оправданости. Када се право и дужност не појављују као апсолутно јединство, онда полазна тачка није право које прати дужност, већ обрнуто. Полазна тачка више није право онога ко прима већ је дужност онога ко даје. Историјски пример за делегитимисање сиромашних као субјеката интересовања јесте хришћанска милостиња (спасење душе као мотив) у чијем је средишту инструментализација давања зарад сопственог спасења, а не због права и захтева сиромашних. На истој равни аргументације можемо посматрати помоћ сиромашнима (добровољно или институционално) зарад очувања друштвене заједнице. Субјективни егоизам се у овом случају губи, али не у корист самих сиромашних већ у прилог очувања друштва. Сходно наведеном, поменута подршка сиромашнима у оба случаја представља средство, а не циљ по себи. Аутор стога истиче да институционалну бригу о сиромашнима прожима врло комплексна социолошка констелација. У погледу садржаја ова помоћ је лична и усмерена ка појединачним случајевима (није усмерена ка свим грађанима као остале јавне инстуције: полиција, војска, школство), али са друге стране оваква заштита сиромашних доприноси читавој заједници спречавајући потенцијалне претње за очување заједнице. Овакво разумевање бриге о сиромашнима нема за циљ њихово изједначавање са богатима, нити узимање од богатих за прерасподелу сиромашнима значи укидање диференцијације између ових категорија, већ напротив. Незнатним ублажавањем екстремног друштвеног раслојавања путем прерасподеле (давање помоћи сиромашнима) репродукује се постојећа структура друштва. У том смислу, прерасподела која се врши у корист читавог друштва појединцу пружа само ону количину добра која је неопходна да се одржи status quo (централистичка телеологија).

Сумарно, у модерном приступу „помоћ сиромашнима“ није циљ по себи, нити је сиромах сврха по себи, али је као део телеолошког ланца ипак органски део целине и као такав води остварењу циљева колектива. Заједница преузима на себе терет збрињавања сиромашних из практичних разлога: централистички је усмерена и посредством државних органа и законских регулатива сиромашни добијају своју формалну позицију. Прописујући право на помоћ категорији сиромашних, али и дужности колектива у њиховом збрињавању, значајну улогу имају друштвени органи и групе који раде на њиховом збрињавању.

Са појавом идеала хуманости и људских права, истискује се централистичко гледиште које подразумева обезбеђивање посла сиромашнима као општем друштвеном интересу (Енглеска, workhouses), док је акценат на обезбеђивању егзистенцијалног минимума свима без условљања радом. Важна питања која аутор проблематизује јесу: чија је обавеза збрињавања сиромашних (шире друштво, локална заједница или појединци); како се мења и модификује природа помоћи и улога државе; начин финансирања помоћи; подела задата- 
ка и ефикасност располагања средствима. Посебно питање тиче се обухвата и издашности помоћи материјално угрожених што и даље представља предмет многих дебата у данашњици.

У поглављу Екскурс о негативности колективног начина понашања аутор указује на чињеницу да је знатно лакше окупити људе око онога што заједно не желе, него да се усагласе око жељеног. Негативни карактер везе који уједињује неку велику групу показује се најпре у нормама исте. Уколико је нека група већа, па самим тим и разноврснија, утолико је неопходније да се односи унутар ње регулишу путем негативних норми (забрана). Што је број чланова већи, то су норме општије и једноставније. Са малим бројем норми лакше је очувати велику него малу групу. Поштовање норме која је општа, мање је карактеристична и битна за појединца, али њено кршење по правилу има велике и упадљиве последице (поздрав на улици још није доказ поштовања, али одсуство поздрава јасан је знак непоштовања). Сходно реченом, потпуно је у складу са поступањем широке заједнице да све што та заједница предузима за сиромашне буде ограничено на минимум. Таква врста (минималне) помоћи има објективни карактер јер је очување сиромашних од физичке беде свим субјектима колектива јасан, једнозначан и општеприхваћен критеријум процене. Израз објективности неког става јесте његова општеприхваћеност. Када бригу о сиромашнима преузме држава, не полази се само од интереса сиромаха већ и од интереса заједнице (постављање граница). Сиромах треба да добије оно што му правично припада, не премало, али не и превише.

Сходно томе, сиромаштву можемо приступити на два начина: 1. као појави коју је могуће објективно установити; 2. као усмерености на материјално депривираног појединца имајући у виду индивидуалност случајева и уклањању узрока. У првом случају држава решава питање објективног постојања феномена, док се узроцима индивидуалне природе бави приватно доброчинство. Већу пажњу аутор посвећује објашњењу да је група сиромашних објекат акција које спроводи група (институционални аранжмани помоћи), самим тим их одваја и дистанцира од целине, стигматизује и изолује. Упркос наведеном, сиромашни нису ван заједнице. Они су укључени у односе заједнице и без те групе заједница не би изгладала као што изгледа.

Зимел указује на релативан карактер појма сиромаштва, проблематику утврђивања потреба, али и границе апсолутног сиромаштва. Сваки друштвени слој има своје типичне потребе и циљеве, док се сиромашним сматра свако ко није у стању да их задовољи. Међутим, материјалне аранжмане не примају сви сиромашни већ само они који су у апсолутној потреби (храна, одећа, кров над главом). У социјалном смислу, сиромашним се сматра онај коме је пружена помоћ, сходно чему примање помоћи представља главни критеријум за сврставање у ову групу. Занемарујући њено индивидуално значење и захваљујући социјалном смислу речи „сиромашан“ - они чине хомогени слој у оквиру друштва. За разлику од средњег века, у модерном друштву видљива је тенденција скривања сиромаштва која исте држи удаљене једне од других и не дозвољава да се развије осећај припадности друштвеној групи (класи). 
Сумарно, класа сиромашних у модерном друштву продукт је специфичне синтезе: по значају и месту које заузима у друштву представља хомогену класу, али ако се разматрају појединачне одредбе њених елемената онда се губи. То је резервоар најразличитијих људских судбина без заједничких садржаја који би их ујединили и изазвали осећај међусобне припадности. Аутор на крају поентира објашњењем сиромаштва као јединствене социолошке констелације. Појединци су на основу својих јединствених животних судбина/позиција органски чланови заједнице у којој заузимају посебно место, а то место је одређено делањем појединаца, удружења или читаве заједнице која покушава ту ситуацију да поправи. Социолошки гледано, сиромашан није „онај који лично не поседује средства, него онај коме се због тога пружа помоћ““ (83).

Посебан дојам на крају ове књиге пружају нам слике и фотографије сиромаштва из 19. и 20. века уз коментаре и објашњења Дејана Аничића. 